\title{
The Dilemma of Reading, Writing, and Counting in Early Childhood Education: A Qualitative Descriptive Study
}

\author{
Hana Tiara Pertiwi ${ }^{1,}$ Yudianto Sujana ${ }^{1,}$ Adriani Rahma Pudyaningtyas ${ }^{1}$ \\ ${ }^{1}$ Teacher Education for Early Childhood Education, Universitas Sebelas Maret
}

\begin{abstract}
Playing with children can optimize child development, provide life experience and is the fundamental right of children, however, pencil and paper have become a regular activity for children in this era. Although many studies have concluded that learning to read, write and count is not necessary for early childhood, there are many Early Childhood Education (ECE) still applying it. It happens because of a dilemma between the curriculum and the willingness of parents. This article is the result of qualitative descriptive research that discussed why it happened and how to overcome it. Data collected from ECEs in Karanganyar, Indonesia and Wat Donmuang School in Bangkok, Thailand. The results show that the desire to teach reading, writing and counting to children is not from the ECE, but from the parents who consider that the smart child is a child who can read, write and count. Beside it, several excellent primary schools require the prospective students able to read, write and count. The practical implication of this paper is to widen the perspective of ECE that they don't need academic achievement only but affection and maturation should be the foundation of education.
\end{abstract}

Keywords: early childhood education; reading; writing; counting

\section{INTRODUCTION}

Early childhood is the child who is in the age range 0 to 8 years which is also called the golden age. This age is the period when the child's brain is growing rapidly by about $85 \%$ when reaching the age of 5 years with more than 100 million neurons connected [1]. Child development occurs continuously and moves up, starting from simple to complex patterns in line with his age [2]. Aspects of child development include cognitive, physical, linguistic, and socio-emotional development [3]. The non-repetitive period of golden age requires proper attention and stimulation to optimize child development.

Playing bridges child development. Playing through real, live, and meaningful activities contributes to optimizing child development [4]. Playing is also beneficial for the cognitive, physical, social-emotional, and welfare development of children [5], and through play also children learn to solve problems, think, socialize, and mature [6]. Therefore, children need to have time, space, and freedom to expand and enrich the experience that will impact on their development [7]. Both positive and negative experience can cause a snowball effect [8]. Social experience helps children to develop 
social skills, e.g., befriending [9] whereas exposure to stress from the environment can affect neural development, resulting in adverse childhood experiences [10].

Every aspect of child development is equally important to develop. However, many assumptions that the cognitive aspect is the most important. Cognitive aspects include perception, information processing, language comprehension, and visual attention [11], and the introduction of literacy and numeracy [12]. Cognitive development is concerned with the process of individuals acquiring, organizing, and using knowledge [13] and learning skills [14]. Cognitive abilities considered the most important is to read, write and count. Here there is a gap between playing that is the essence of the child and learning to read, write, and count for the preparation of children to elementary school.

Lack of knowledge about child development aspects makes learning to read, write and count directly into something commonly done in kindergarten. Children are taught to read, write and count using books and pencils like primary school students. The existence of reading, writing, and counting activities is considered reasonable by peoples to equip children entering the primary school education level. Children who have reading, writing and counting skills will have self-independence, and not dependent on others when completing a task [15].

Learning to read, write, and count becomes an orientation within the scope of Early Childhood Education, especially kindergarten. When the researcher conducted the teaching practices at Wat Donmuang School Thailand, the learning activities carried out with pencil and book. Teachers prepared the children since group A to follow the more complex learning of reading, writing, and counting in group B. Also, the teachers in group B won't accept children with no reading, writing, and counting skill. In fact, learning to read, write and count also happened in Indonesia, a kindergarten in the Karanganyar area, provides learning to read, write, and count for 30 minutes twice a week. Moreover, most primary schools require new students have mastered reading, writing, and counting, so the majority of parents feel confident when they children have reading, writing, and counting skill.

Stages of cognitive development affect children's learning process. Early childhood thinking is at the pre-operational stage of learning something contextual [2] not something abstract like letters and numbers. The child's thinking process occurs when there is a chance and personal response to play and explore, speculate, question, imagine, and possibly think ahead [16]. The pressure of academic burden from an early age tends to take a playing period which is a learning medium. However, there is suitable stimulation for the introduction of literacy and numeracy, such as involving children in daily activities that embedding the concept of reading, writing, and counting [17].

Child privileges and learning processes within the scope of early childhood education, including the dilemma of reading, writing, and counting learning are challenging study material. Based on the above exposure, the researcher is interested in elaborate descriptive qualitative research, which is reading, writing, and counting in Early Childhood Education.

\section{METHOD}

This study used a qualitative descriptive method which will outline the findings of the application of learning to read, write and count in kindergarten Thailand Wat 
Donmuang School and several kindergartens in the district of Karanganyar, Central Java, Indonesia. Data collection methods used are (1) Observation conducted to know the condition in the field related to reading, writing, and counting learning in the scope of Early Childhood Education. (2) Literature studies from various data relevant to this research topic. (3) Interviews conducted to strengthen the arguments and look at the particular point of view. (4) Document investigation such as video recording and photographs of the teaching and learning activities in Early Childhood Education.

\section{RESULTS}

\section{The Dilemma of Reading, Writing and Counting in Early Childhood Education}

Playing is the child's nature and can be the learning tool for children. With the concept of playing while studying or learning while playing [18] the learning process will be more fun. Playing also has a positive effect, as children playing with friends have the positive effect of adaptation during the transition to primary school [19]. Playing can also support cognitive, social and physical motor development and can combine with various learning topics [20], so the class should have more playing activity opportunities that children can choose. Besides, playing also improves children's cognitive flexibility [21].

Nowadays, teachers are encouraged to present interactive and challenging learning activities to stimulate children [4]. However, the reality sometimes is very far from the expectations, the competition to enter favorite primary school, began to obscure the perspective of early childhood learning. Reduction of playing activities was taken over by the cognitive learning given by teachers to raise children standards [22]. Playing time is reduced and replaced by academic priorities as the child grows older to get to primary school [7].

Many kindergartens provide the learning of reading, writing, and counting to exist in the market. Based on interviews with some kindergarten teachers it is known that kindergarten has no choice because parents are requesting the teacher to prepare the children for primary school which requires the prospective students can read, write and count. Also, parents assume that a smart child should be able to reading, writing, and counting from an early age. Schools will also lose students if they do not provide reading, writing, and counting in teaching and learning activities. The teacher realizes that the government strictly prohibits reading, writing, and counting, but to meet consumer demand they still teach it.

Full day school system is applied at all levels of education in Thailand, including Early Childhood Education (Kindergarten). Wat Donmuang School held teaching and learning activities that begin at 8.00 to 14.00 at local time, but children can stay in school until 16.00 if not yet picked up. Learning in class is set without chairs, so the child sits on the floor. The A2 group, consisting of 30 children with two teachers. The children have a lot of work books and work sheets just like primary school students. In general, children in groups A are 4-5 years old; they are pressured to master literacy mainly Thai language, and numeracy in counting by working on worksheets [23]. Sometimes the children are asked to come forward to pronounce the letters and numbers. 
Academic demands require children to hold pencils and books every day. Every day, a child using three books, which is coloring activity, thickening and copying letters and numbers. Besides, children also have to do homework and have to collect it on the next day. Teachers led reading and counting activities in the classical setting. In morning children are given stimulation in the form of reading a story book to stimulate interest in reading. Also, instructional media creates with a lot of writing so that children are familiar with the letters. Meanwhile, learning the numbers using the number on the board.

The assignment should be done by the children no matter how tired or lazy they are. Some children seemed to massage their small hands as if exhausted, then resumed. There are also children who do not want to do it, then the teacher rebukes and forces him to do his job. The children get breaks during lunch and take a nap in class. Meanwhile playing in the playground is not allowed, though the school its area on the corner of the building but it locked. The kids played a lot in the room with the available games and played by sitting. Some children running around would be reprimanded and asked him to sit. Their radiant faces will appear when parents pick up to go home.

Half day school became the standard in the majority of Early Childhood Education (kindergarten) in Indonesia. Children are given writing, reading, and counting exercises that are inserted into the core activities. Even children worksheet should exist as a learning evaluation at the end of the day. Not a few teachers who provide additional training to write, read, and count after school. Contrary to the Early Childhood Curriculum 2013 at the base competence point 3. Presented that the context of learning to read, write, and count using playing approach and adapted to the task of child development.

Teachers are in control of teaching and learning activities in the classroom. Educators' knowledge with an Early Childhood Education degree is positively associated with language teaching and literacy instruction [24]. Based on observations, the majority of kindergarten teachers in Thailand have an attitude that is leaning toward authoritarian discipline. If children have not finished working, then they don't allow to follow the next activity. Teachers often grumbled when children don't do the tasks as instructed. This makes the child depressed because of coercion, so this does not optimize the development of children. Whereas the relationship between teachers and students is positively correlated in learning literacy and development [25]. On the other hand, a student internship at the school said that teachers stated there is no time to play because of the child must learn. While the kindergarten teachers in Indonesia are more likely to guide when children are given tasks that require writing skills. Reading and counting activities are done with the same stimulation.

It is a public secret that kindergarten has learning activities that are oriented towards mastery of reading, writing, and counting. Full day school and half day school have a significant impact on reading, writing and counting skills. Children in full-day schools experience early reading achievement than children in half-day schools because the focus of full day schooling is the academic ability of the child [26]. However, academic interventions in the full day classes did not last long, initially improving reading and math achievement [27]. The acquisition of literacy skills in full day classes with more than 24 children is at a slower rate than children in smaller full day classes and large half-day classes [28]. 


\section{The Solution}

Reading, writing, and counting skills are developed through modifications to the conditions around the child. Adjusting the classroom environment according to the child's development stage [29] and teacher innovation [21] can help smooth the teaching and learning process. A supportive environment, the interaction of children with knowledgeable and trusting adults encourages children to be actively engaged and interested in reading, writing, and counting [25]. Furthermore, there are lots of fun way for the kindergarteners to learn about reading, writing, and counting.

Using challenging learning style for kindergarteners. Learning based on Beyond Center and Circle Time (BCCT) approach is considered to enable children to learn [30]. The center and circle approach focuses on children who are in the learning process centered in the center of play and when a child is in a circle with four types of footholds to support child development, namely (1) footing environmental of play, (2) footing before the play, (3) footing during play; and (4) footing after play.

Learning to read, write, and count not only with pencils and books. However, involving children on daily activities that contain the concept of reading, writing, and counting because the concept is around children. Play activities should provide meaningful learning contexts [31] so that when children are involved, children tend to produce long-term understanding and concept development.

Story time is one of the tools to develop reading skills. Story time builds habitual thinking that helps the child listen with understanding which is then able to read with understanding [32]. The interactive reading of books through book-share, read-aloud, and the wordless picture book is another method of assisting in the development of reading skills [33].

Arranging the classroom situation for the development of writing skills. The classroom can be equipped with an alphabet to familiarize children with literacy and write the child's name in the child's daily routine [34]. Drawing and crossing out guides the child to achieve writing skills. Drawing and crossing out guides the child to achieve writing skills. The children will soon be able to distinguish whether it's a picture and writing graffiti, or a shape that resembles the letter as children experiment with writing [17].

The development of numeracy skills is included in the mathematical concepts that are close and experienced by children every day. Involving children in daily activities help them to understand the conceptual rather than just with books and pencils. Mathematical experience can convey meaningful mathematical concepts, such as measuring-filling glasses while cooking, shape-aware forms, estimating lengthencouraging children to determine object size, and sharing-while eating snacks, Sitting around the table and counting the number of children there [35].

The progress of time encouraging the use of media that is integrated with the education system. The use of media can be applied in teaching and learning activities to support children's reading skills [36] such as reading e-books as the tool to develop word readings, vocabulary extensions, and story comprehension [37]. However, various forms of stimulation for the development of reading, writing and numeracy skills need to be accompanied by knowledgeable and trusted adults. In addition, coercion of children leads to adverse experiences for cognitive development [38]. 


\section{CONCLUSION}

Academic demands have an influence on children's development. Mastery of skills pursued to meet a standard then makes kindergarten no longer a kindergarten. Supporting children to master reading, writing and counting skills are tailored to their developmental stages, environmental support, and positive interest in children. Moreover, classroom settings contribute to adaptation of children to higher education levels of kindergarten [39]. Indeed, Kindergarten is the place for children develop the potential through the nature of learning in the form of play. Structured play activities maximize the learning process of children [31]. Nevertheless, the trend of parents who want a favorite elementary school requires children to master reading, writing, and counting, either to pass the entrance exam or guarantee to follow the learning activity. However, this goes back to the parents and the kindergarten teachers. Lastly, organizing the environment is better than setting the child to fit in the environment, because childhood is the foundation of life.

\section{REFERENCES}

[1] Rushton, S. (2011). Neuroscience, Early Childhood Education and Play: We are Doing it Right! Early Childhood Education Journal, 39(2), 89-94. https://doi.org/10.1007/s10643011-0447-z

[2] Susanto, A. (2011). Perkembangan Anak Usia Dini: Pengantar dalam Berbagai Aspeknya (First). Jakarta: Kencana Prenada Group.

[3] Padmonodewo, S. (2003). Pendidikan Anak Prasekolah. Jakarta: PT Rineka Cipta.

[4] Ciolan, L. E. (2013). Play to learn , Learn to play . Creating better opportunities for learning in early childhood. Procedia - Social and Behavioral Sciences, 76, 186-189. https://doi.org/10.1016/j.sbspro.2013.04.096

[5] Kennedy, A., \& Barblett, L. (2010). Supporting the Early Years Learning Framework. Deakin West ACT: Early Childhood Australia Inc.

[6] Anderson-McNamee, J. K. (2010). The Importance of Play in Early Childhood Development. Family and Human Development, 1-3. Retrieved from https://www.msuextension.org/health/documents/MT201003HR.pdf

[7] Brown, M. H., \& Freeman, N. K. (2015). "We don’t play that way at preschool”: The moral and ethical dimensions of controlling children's play. Early Education and Care, and Reconceptualizing Play.

[8] National Association for the Education of Young Children. (1997). Developmentally appropriate practice in early childhood programs serving children from birth through age 8. Young Children, 1-22.

[9] Nissen, H., \& Hawkins, C. J. (2008). Observing and Supporting Young Children's Social Competence. Dimensions of Early Childhood, 36(3), 21-30.

[10] Sheridan, M. A., \& McLaughlin, K. A. (2014). Dimensions of early experience and neural development: deprivation and treat. Trends in Cognitive Sciences, 18(11), 580-585. https://doi.org/https://doi.org/10.1016/j.tics.2014.09.001

[11] Spencer, J. (2005). Understanding Child Development. Young Consumers, 6(1), 16-21. https://doi.org/doi.org/10.1108/17473610510814372

[12] Fleer, M., \& Raban, B. (2010). Literacies in Early Childhood: The Preschool Period. Early Childhood Education and Care Program, 75-80. https://doi.org/https://doi.org/10.1016/B9780-08-044894-7.01185-4

[13] Gauvain, M., \& Richert, R. A. (2015). Cognitive Development (Encycloped). Oxford: Academic Press. https://doi.org/https://doi.org/10.1016/B978-0-12-397045-9.00059-8

[14] Klingberg, T. (2014). Childhood cognitive development as a skill. Trends in Cognitive Sciences, 18(11), 573-579. https://doi.org/10.1016/j.tics.2014.06.007 
[15] Pratiwi, E. (2015). Kecerdasan Mental Anak. "Inovasi Pembelajaran untuk Pendidikan Berkemajuan.” Ponorogo. Retrieved from http://semnas.fkip.umpo.ac.id/wpcontent/uploads/2015/12/033-Ema-Pratiwi.pdf

[16] Cremin, T., Burnard, P., \& Craft, A. (2006). Pedagogy and possibility thinking in the early years. Thinking Skill and Creativity, 1, 108-119. https://doi.org/10.1016/j.tsc.2006.07.001

[17] Fleer, M., \& Raban, B. (2007). Early childhood literacy and numeracy: building good practice. Canberra: Canberra Department of Education, Employment and Workplace Relations. Retrieved from http://trove.nla.gov.au/work/37558016?selectedversion=NBD45798227

[18] Slunjski, E., \& Ljubetić, M. (2014). Play and Its Pedagogical Potential in a Preschool Institution. Croatian Journal of Education, 16(1), 127-141.

[19] Eggum-Wilkens, N. D., Fabes, R. A., Castle, S., Zhang, L., Hanish, L. D., \& Martin, C. L. (2014). Playing with others: Head Start children's peer play and relations with kindergarten school competence. Early Childhood Research Quarterly, 29(3), 345-356. https://doi.org/http://dx.doi.org/10.1016/j.ecresq.2014.04.008

[20] Azlina, W., \& Zulkiflee, A. S. (2012). A Pilot Study: The Impact of Outdoor Play Spaces on Kindergarten Children, 38(December 2010), 275-283. https://doi.org/10.1016/j.sbspro.2012.03.349

[21] Ansari, A., \& Purtell, K. M. (2017). Early Childhood Research Quarterly Activity settings in full-day kindergarten classrooms and children's early learning. Early Childhood Research Quarterly, 38, 23-32. https://doi.org/10.1016/j.ecresq.2016.09.003

[22] Frost, J. L., Wortham, S. C., \& Reife, S. (2007). Play and Child Development. Upper Saddle River, NJ: Pearson/Merrill Prentice Hall.

[23] Chanbanchong, C. (2014). Education and Care for Early Childhood in Thailand: An Overview and the Observation of Six Kindergartens.

[24] Schachter, R. E., Spear, C. F., Piasta, S. B., Justice, L. M., \& Logan, J. A. R. (2016). Early childhood educators' knowledge, beliefs, education , experiences , and children's languageand literacy-learning opportunities: What is the connection? Early Childhood Research Quarterly, 36, 281-294. https://doi.org/10.1016/j.ecresq.2016.01.008

[25] White, K. M. (2013). Associations between teacher - child relationships and children's writing in kindergarten and first grade. Early Childhood Research Quarterly, 28(1), 166-176. https://doi.org/10.1016/j.ecresq.2012.05.004

[26] Thompson, J. A., \& Sonnenschein, S. (2016). Full-day kindergarten and children's later reading: The role of early word reading. Journal of Applied Developmental Psychology, 42, 58-70. https://doi.org/http://dx.doi.org/10.1016/j.appdev.2015.11.005

[27] DeCicca, P. (2007). Does full-day kindergarten matter? Evidence from the first two years of schooling. Economics of Education Review, 26, 67-82. https://doi.org/10.1016/j.econedurev.2005.04.003

[28] Zvoch, K., Reynolds, R. E., \& Parker, R. P. (2008). Full-day kindergarten and student literacy growth: Does a lengthened school day make a difference? Early Childhood Research Quarterly, 23(1), 94-107. https://doi.org/http://dx.doi.org/10.1016/j.ecresq.2007.08.001

[29] Maggi, S., Irwin, L. G., Siddiqi, A., Poureslami, I., Hertzman, E., \&, \& Hertzman, C. (2011). International Perspectives on Early Child Development. Human Early Learning Partnership, 39(5), 758-772. https://doi.org/10.1016/j.worlddev.2010.10.008

[30] Latif, M., Zukhairina, Zubaidah, R., \& Afandi, M. (2013). Orientasi Baru Pendidikan Anak Usia Dini: Teori dan Aplikasi (First). Jakarta: Kencana Prenada Group.

[31] Gilbert, J. L., Harte, H. A., \& Patrick, C. (2011). Purposeful Play Leads to School Readiness. Dimensions of Early Childhood, 39(1), 29-38.

[32] Moore, M. R., \& Hall, S. (2012). Listening and Reading Comprehension at Story Time: How to Build Habits of the Mind. Dimensions of Early Childhood, 40(2), 24-32. Retrieved from http://search.ebscohost.com/login.aspx?direct=true\&profile=ehost\&scope=site\&authtype=cra wler\&jrnl=10686177\&AN=78303872\&h=F/r0Co5cBJuJKvJGqL6NkSLOGpvDj6JQccTxM eROjw/06E61CB7RQBnDqOHTskd/09gsMmFeo4iXDjMW0rfVxA==\&crl=c

[33] Chaparro-Moreno, L. J., Reali, F., \& Maldonado-Carreño, C. (2017). Wordless picture books boost preschoolers' language production during shared reading. Early Childhood Research Quarterly, 40, 52-62. https://doi.org/10.1016/j.ecresq.2017.03.001 
[34] Puranik, C. S., Lonigan, C. J., \& Kim, Y. (2011). Early Childhood Research Quarterly Contributions of emergent literacy skills to name writing, letter writing, and spelling in preschool children. Early Childhood Research Quarterly Contributions, 26, 465-474. https://doi.org/10.1016/j.ecresq.2011.03.002

[35] Queensland kindergarten learning guideline. (2014). Supporting Language and Early Literacy Practices in Kindergarten. Queensland. Retrieved from https://www.qcaa.qld.edu.au/downloads/p_10/qklg_pd_resource_supporting_literacy.pdf

[36] Ivanovi, M. (2014). Development of Media Literacy - an Important Aspect of Modern Education, 149, 438-442. https://doi.org/10.1016/j.sbspro.2014.08.284

[37] Korat, O. (2010). Computers \& Education Reading electronic books as a support for vocabulary, story comprehension and word reading in kindergarten and first grade. Computers \& Education, 55(1), 24-31. https://doi.org/10.1016/j.compedu.2009.11.014

[38] Loughlin-Presnal, J. E., \& Bierman, K. L. (2017). Promoting parent academic expectations predicts improved school outcomes for low-income children entering kindergarten. Journal of School Psychology, 62, 67-80. https://doi.org/https://doi.org/10.1016/j.jsp.2017.03.007

[39] Broekhuizen, M. L., Mokrova, I. L., Burchinal, M. R., \& Garrett-Peters, P. T. (2016). Classroom quality at pre-kindergarten and kindergarten and children's social skills and behavior problems. Early Childhood Research Quarterly, 36, 212-222. https://doi.org/http://dx.doi.org/10.1016/j.ecresq.2016.01.005

[40] Chiara, M., Lanfranchi, S., Altoè, G., \& Sollazzo, N. (2015). Early numerical abilities and cognitive skills in kindergarten children. Journal of Experimental Child Psychology, 135, 2542. https://doi.org/10.1016/j.jecp.2015.02.001

[41] Clements, D. H., Fuson, K. C., \& Sarama, J. (2017). The research-based balance in early childhood mathematics: A response to. Early Childhood Research Quarterly, 40(February), 150-162. https://doi.org/10.1016/j.ecresq.2017.03.005

[42] Goldstein, J. (2012). PLAY IN CHILDREN'S DEVELOPMENT, HEALTH AND WELLBEING, (February).

[43] Kernan, M. (2007). Play as a context for Early Learning and Development. Dublin.

[44] Lockhart, S. (2010). Play: An Important Tool for Cognitive Development. HighScope Extensions, 24(3), 1-8. Retrieved from http://membership.highscope.org/app/issues/142.pdf

[45] Miller, E., \& Almon, J. (2009). Crisis in the Kindergarten: Why Children Need to Play in School. College Park: Alliance for Childhood. 